\title{
Ecological Study of Sea Cucumber Central Moluccas
}

\author{
D. A. J. Selanno ${ }^{1}$, Y.L. Natan ${ }^{2}$, Pr. A. Uneputty ${ }^{3}$, Y. A. Lewerissa ${ }^{4}$ \\ ${ }^{1-4}$ (Faculty of Fisheries and Marine Sciences, University of PattimuranAmbon - Indonesia)
}

\begin{abstract}
Teripang (Sea cucumber) is one of echinoderm members which has an important economical value and can be found in Moluccas Waters. Among Sea cucumber in Moluccas, H. scabra, H. nobilis, H. edulis, H. atra, T. ananas, and B. argus have been mass exploited causing the decreasing not only in their kind but also in their quantity. This study aims to determine the ecological condition of Sea cucumber in four locations in Central Moluccas Regency from July to December 2013. The results showed that there was the presence of species composition variety, density, different distribution pattern among locations. Diversity and similarity of Sea cucumber species among those locations were obtained to be low category.
\end{abstract}

Keywords: Ecology, Echinoderm, Sea cucumber, Central Moluccas

\section{Introduction}

In Moluccas there are six Sea cucumber which have been exploited such as teripang pasir (H. scabra), teripang batu (H. nobilis), teripang batu keling (H. edulis), teripang perut merah (H. atra), teripang ananas $(T$. ananas), and teripang patola (B. argus) [1],[2]. Teripang (Sea cucumber) has been known as a delicious food in several countries such as China, Japan, Corea including USA [1],[3] It is caused by teripang has the high nutrient contain with protein, fat, water, mineral, and ash content composition of $43,2,17,21$, and $7 \%$, respectively. It has been also repoted as drug which has a curative effect [4],[5].

The main source areas of teripang in Indonesia comes from Moluccas particularly Southeast Molluccas [6],[7]. Nevertheless, population and size of teripang in this Province have decreased [7],[8]. Yusron (2001) reported that the density of teripang in Morela was only about 0,09-1,03 ind $\mathrm{m}^{-2}$, whilst Malik (2013) obtained

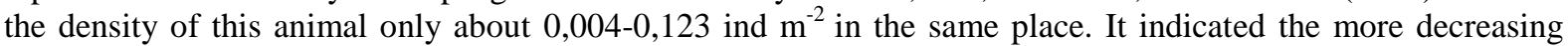
occurence of teripang during 11 years [1],[9].

This study aims to determine the ecological condition factors of teripang for management purpose. By the knowing of the teripang ecological condition, it can be made a prediction in the future about the condition of teripang culture and create a suitable and continuing management model to solve teripang culture problems.

\subsection{Time and Place of Research}

\section{Method Of Research}

This study was carried out in July to September 2013 in four places in Central Moluccas namely, Suli, Morela, Ihamahu (P. Saparua), and Pelauw (P. Haruku) desa (Figure1).

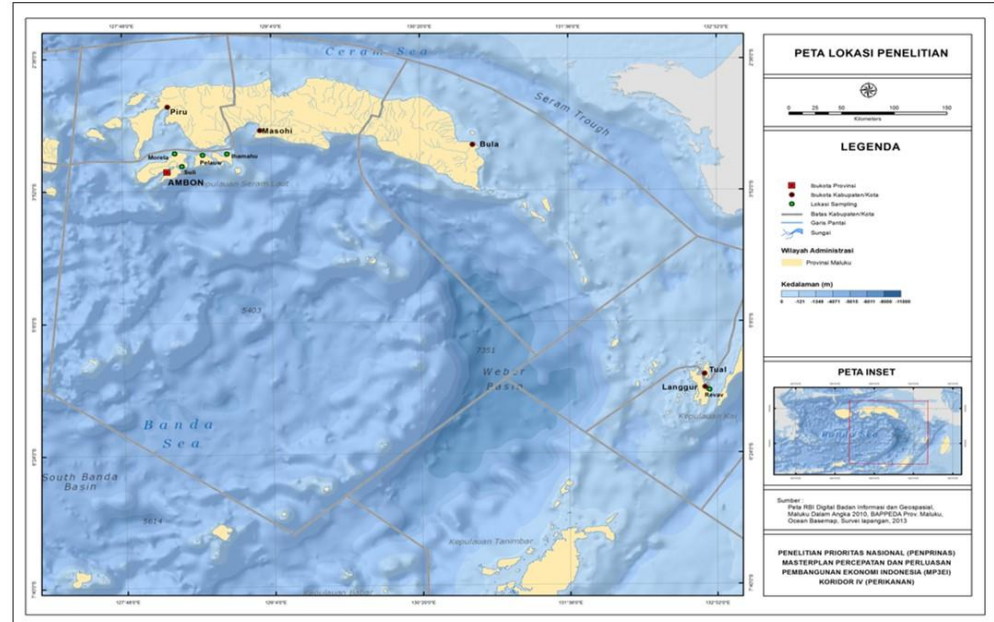

Figure 1. Location of study in Central Moluccas

\subsection{Equipments and Materials of Research}

Equipments and materials of research are listed in Table 1 
Table 1 Equipments and Materials and their function

\begin{tabular}{|l|l|l|}
\hline No. & Equipment & Function \\
\hline 1. & White board and Stationery writing & To write the result of observation in the field \\
\hline 2. & Nylon strap & As transect strap \\
\hline 3. & Roll meter & To measure transect line and observation quadrate \\
\hline 4. & Float wooden and sinker & $\begin{array}{l}\text { To mark the point in transet, point marker and } \\
\text { squared }\end{array}$ \\
\hline 5. & Digital camera & To take documentation of activities in the field \\
\hline 6. & Plastic bag & To put sample and substrate \\
\hline 7. & Refractometer & To measure sea water salinity \\
\hline 8. & Thermometer & To measure waters temperature \\
\hline 10. & pH meter & To measure pH \\
\hline 11. & DO meter & To measure dissolved oxygen \\
\hline 12. & GPS & To determine the location position \\
\hline 14. & Tray and basin & To place sample \\
\hline 15. & Ruler (cm) & To measure the length of teripang \\
\hline 16. & Digital balance $(\mathrm{g})$ & To measure the weight of teripang \\
\hline
\end{tabular}

\subsection{Sample collection method}

Sampling method used was a quadrate linear transect. Transect line was drawn perpendicular to the direction of the sea. Along transect line chosen were placed quadrates sizing of $10 \times 10 \mathrm{~m}$. Teripang species each obtained in the quadrates was counted and separately kept in plastic container containing sea water. Each teripang was then settled for \pm 10 minutes and continued for measuring of length and weight. One to two of each species of teripang was taken out for being documented its dorsal and ventral tissue by using digital camera and fixated in $70 \%$ alcohol for identification process by using method as described by Clark and Rowe (1971), Susetiono (2004 \& 2007) [10],[11],[12]. Data was analyzed as described by Odum (1971\},Khouw (2009), and Bakus, (2007). [13],[14],[15]. In situ environment parameters measured were temperature, salinity, pH, DO by using thermometer, refractometer, $\mathrm{pH}$ meter, and $\mathrm{DO}$ meter, respectively.

\subsection{Data Analysis}

The density of teripang species was measured by equation as followed:

Density $\left(\mathrm{ind} / \mathrm{m}^{2}\right)=$

$$
\text { Number of species each }
$$

$$
\text { Square wide }
$$

Relative density $(\%)=$

Density of species each

Density total of all species X $100 \%$

Square number of where species each obtained

Frequency of the presence (ind $/ \mathrm{m}^{2}$ )

Relative presence frequency $(\%)=$

Square number total

Presence frequency of species each

Presence frequency total of all species

X $100 \%$

The other ecological parameters of teripang were counted based on Odum (1975)[16]. indexes as followed:

* SHANNON-Wiener $\left(\mathrm{H}^{\prime}\right)$ species variety index to determine the variety of echinoderm was counted by equation as followed:

a.

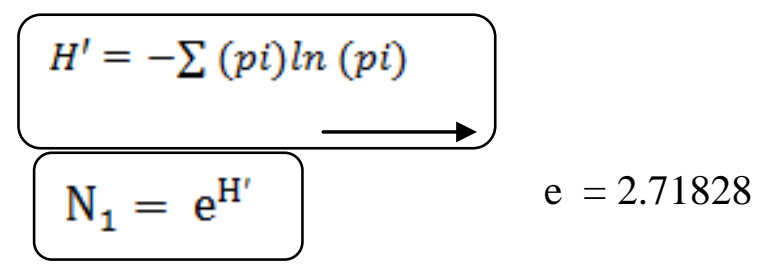


Equation (b) was used to determine the common species of teripang obtained.

* Spesies concurrence index (e) - (EVENESS- SHANNON) to determine concurence among echinoderm species was counted by equation as followed:

$$
e=\frac{H^{\prime}}{\ln S}
$$

* SIMPSON (D) species dominance index was counted by equation as followed:

Note :

$$
\mathrm{D}=\sum_{i=0}^{s} \frac{n_{i}\left(n_{i}-1\right)}{N(N-1)}
$$

$\mathrm{n}_{\mathrm{i}}: \quad$ Number of species each at that time (ind)

$\mathrm{N}: \quad$ Number of all species (ind)

$\mathrm{p}_{\mathrm{i}}: \quad \mathrm{n}_{\mathrm{i}} / \mathrm{N}$

S : $\quad$ Number of sample species obtained from the observation at that time

Those ecological index value range based on Odum (1971) [13] were as followed:

Shannon species variety index $\quad: \quad ' \mathrm{H}=0-4$

Eveness species concurence index : $\quad \mathrm{e}=0-1$

Species dominance index : $\mathrm{D}=0-1$

Species similarity was counted by using equation as described by Bray-Curtis Similarities.

Those ecological parameters were counted by using software Primer 6.

\subsection{Description of location}

\section{Results And Discussions}

Suli village coastal Waters has gradient topography with variation substrate namely, sandy, muddy, muddy sand, rocky to reef fracture. This study was carried out in segrass of Suli village Waters with position of $128^{0} 18$ '04,3"'-128 ${ }^{0} 18$ '24,5 BT and $03^{0} 37^{\prime} 36,8^{\prime \prime}-03^{0} 37^{\prime} 45,5^{\prime \prime} \mathrm{LS}$.

Distance of ebbtide along of Morela village coastal Waters was around $\pm 200 \mathrm{~m}$ of the limit of highest tide until the lowest tide. Pelauw State coastal Waters has a characteristic ecosystem like tropic region such as mangrove, lamun, and coral reef. Location of study in this state was in the area of high and low tide with gradient coastal and muddy sand, sandy, craggy sand, equivalent of dead coral, and overgrown by algae community such as Sargassum sp. and Laminaria sp. and lamun community of komunitas such as Enhalus acoroides, Cymodocea rotundata and Halodule pinifolia.

Ihamahu State coastal Waters has three tropic main ecosystems namely, mangrove, seagrass with seven species of sea grass such as Enhalus acoroides, Thalassia hemprichii, Cymodocea rotundata, Cymodocea serrulata, Halophila minor, Halodule uninervis and Syringodium isoetifolium nevertheless, there were dominated by Thalassia hemprichii and Cymodocea serrulata) as well as coral reef species.

\section{Quality Parameters of Environment Physical and Chemical}

Teripang in location of study had variety substrates namely, sandy, muddy, rocky, craggy and craggy sandcastle, seagrass sand, and muddy sand. These substrate varieties had the correlation to the presence of particularly teripang species. Teripang could be found in habitat with sandy bottoms covered parts of the reef sea grass. Several species of teripang could be obtained in the habitat with many coral ridges (boulders) and around life reef group [17].

Temperature obtained during the study was range from 24 to $30{ }^{\circ} \mathrm{C}$. This temperature was suitable for the growth of teripang. The optimum temperature for the growth of teripang is $20-25^{\circ} \mathrm{C}$ (Gultom, 2004), $24-30$ ${ }^{\circ} \mathrm{C}$ (Martoyo et al., 1994), and $28-31^{\circ} \mathrm{C}$. Yusron and Widianwari (2004). Meanwhile, salinity was range from 20 to 35 psu. Sukmiwati et al.,2012) reported that the normal salinity for the growth of teripang is range from 30-34 PSU, nevertheless several species of teripang can grow at the salinity of 21 PSU. [18],[19], [20] [21]. 
In addition, $\mathrm{pH}$ and dissolved oxygen (DO) observed during this experiment were range from 7.34 to 7.95 and 5.64-6.53 mg/L, respectively. According to Direktorat Konservasi and Tanaman Nasional Laut (2004) and KepMen Lingkungan Hidup no 51/2004, $\mathrm{pH}$ and DO which are suitable for the growth of teripang are 6,6-8,5 and $6.0-8,0 \mathrm{mg} / \mathrm{L}$, respectively [22],[23].

\subsection{Species Composition}

Species composition obtained in Central Moluccas is listed in Table 2. In the four study locations were found 22 species of teripang consisted 2 ordo (Actinopyga and Apodida), 3 family (Holothuriidae, Stichopodidae and Synaptidae), and 8 genus (Actinopyga, Bohadschia, Holothuria, Thelenota, Stichopus, Opheodosoma, Euapta and Synapta) (Table 2).

In Takofi State Waters, North Moluccas was obtained 8 teripang spesies [24]. Compared to North Moluccas, Central Moluccas has a higher teripang species. Teripang found could be grouped in 3 categories based on their economical value. The great category, having the highest economical value is Holothuria atra, $\mathrm{H}$. scabra and H. edulis. Meanwhile, spesies with the moderate category having the mild economical value are Actinopyga echinites and A. mauritiana and the others were included in the low category with the cheaper economical value. There are also species that have not been used such as species from Synaptidae family well known as "tali kain" in Moluccas.

Table 2. Composition of teripang taxonomy in Central Moluccas

\begin{tabular}{|c|c|c|c|}
\hline Ordo & Family & Genus & Species \\
\hline \multirow[t]{15}{*}{ Aspidochirotida } & Holothuriidae & Actinopyga & A. echinites \\
\hline & & Bohadschia & $\begin{array}{l}\text { A. maurittana } \\
\text { B. argus }\end{array}$ \\
\hline & & & B. marmorata \\
\hline & & & B. similis \\
\hline & & & B. graffei \\
\hline & & & B. tenuissima \\
\hline & & & B. vitiensis \\
\hline & & Holothuria & H. atra \\
\hline & & & H. edulis \\
\hline & & & H. scabra \\
\hline & & & H. rigida \\
\hline & & & H. leucospilota \\
\hline & & & H. hilla \\
\hline & Stichopodiidae & Thelenota & T. anax \\
\hline & & Stichopus & S. vastus \\
\hline \multirow[t]{6}{*}{ Apodida } & Synaptidae & Opheodesoma & O. clarki \\
\hline & & & O. grisea \\
\hline & & & O. glabra \\
\hline & & Synapta & S. maculata \\
\hline & & & S. reticulate \\
\hline & & Euapta & E godefrovii \\
\hline
\end{tabular}

\subsection{Density}

Density of teripang in the four locations is shown in Figure 1.

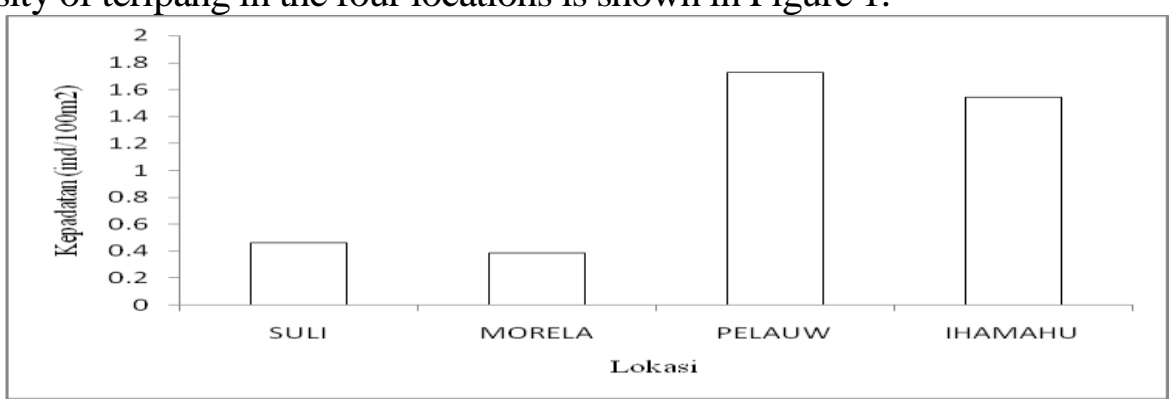

Figure 1. Density of teripang in the four locations in Central Moluccas waters

Teripang in the four locations in Central Moluccas had the variety of density. The highest teripang density in Suli, Morela, Pelauw, and Ihamalu State coastal Waters were Bohadschia similis reaching $0.16 \mathrm{ind} / 100 \mathrm{~m}^{2}$ (35.14\%), Holothuria leucospilota reaching $0.123 \mathrm{ind} / 100 \mathrm{~m}^{2}$ (31.70\%), Opheodosoma grisea reaching 0.4516 ind $/ 100 \mathrm{~m}^{2}$, and Bohadschia similis reaching $0.435 \mathrm{ind} / 100 \mathrm{~m}^{2}$ (27.94\%). Yusron (2004) obtained H. scabra $\left(112 \mathrm{ind} / / 100 \mathrm{~m}^{2}\right)$ as the highest teripang density in Pai Padaido Waters [1].

The presence of the highest teripang density variety was suspected to be caused by their ability to well adapt to the substrates in each location. Bohadschia similis was obtained to well grow on sandy substrate, sandy coral, muddy sand, and dead coral ridge in Sea grass ecosystem. Whilst, muddy sand and seagrass substrate were 
habitats in which $H$. leucosiplota was well grown. Another species of teripang, Opheodosoma grisea, well adapt to sandy substrate grown by Sea grass.

According to Agusta et al.,(2012), substrate type which is dominated by rough sand has a special character giving an effect on eat habitual of teripang. It is due to the rich organic material of sandy bottom substrate. Sandy substrate contains the higher relative oxygen than the softer substrate. Rough sandy substrate consists of air pore which may cause the occurrence of more intensive water mixture. The teripang eat habitual is also effected by physical factors such as ebbtide, current and biological factors as well as ecological factors such as food supply and the ability of teripang to adapt and competing in the occupied habitat which are suitable for the teripang species [24], [25].

\subsection{Presence Frequency and Distribution}

Presence frequency and distribution of teripang are shown in Table 3.

Table 3. Presence frequency (\%) and distribution pattern of teripang in Central Moluccas

\begin{tabular}{|l|l|c|c|c|c|l|}
\hline No. & Spesies & Suli & Morela & Pelauw & Ihamahu & $\begin{array}{l}\text { Distribution } \\
\text { pattern }\end{array}$ \\
\hline 1. & Actinopyga mauritiana & 1.92 & - & - & - & - \\
\hline 2. & Bohadschia marmorata & 1.92 & 2.941 & 5.52 & 23.17 & $\begin{array}{l}\text { Random, } \\
\text { Group }\end{array}$ \\
\hline 3. & B. similis & 30.79 & - & 0.92 & 17.48 & $\begin{array}{l}\text { Similar, } \\
\text { Group }\end{array}$ \\
\hline 4. & Holothuria rigida & 1.92 & - & - & - & - \\
\hline 5. & H. atra & 7.70 & 17.647 & 18.89 & 25.20 & Group \\
\hline 6. & H. leucospilota & 28.87 & 23.529 & 4.60 & - & Group \\
\hline 7. & H. scabra & 13.47 & - & 4.14 & 9.35 & Group \\
\hline 8. & H. hilla & 13.47 & - & - & - & - \\
\hline 9. & B. argus & - & 14.706 & - & 1.22 & Similar \\
\hline & & & & & & \\
\hline 10. & B. graeffei & - & 8.824 & - & - & Similar \\
\hline 11. & Thelenota anax & - & 14.706 & - & - & Group \\
\hline 12. & H. edulis & - & 14.706 & - & 8.94 & Group \\
\hline 13 & Euapta godeffroyi & - & 2.941 & - & - & Random \\
\hline 14. & A. echinites & - & - & 1.38 & 2.03 & Similar \\
\hline 15. & B. tenuissima & - & - & 11.98 & - & Group \\
\hline 16. & B. vitiensis & - & - & 3.68 & - & Kelompok \\
\hline 17. & Stichopus vastus & - & - & 0.92 & - & Similar \\
\hline 18 & Opheodosoma grisea & - & - & 25.80 & 5.69 & Group \\
\hline 19. & O. glabra & - & - & 22.11 & - & Group \\
\hline 20. & O. clarki & - & - & - & 2.85 & Group \\
\hline 21. & Synapta maculate & - & - & - & 2.44 & Similar \\
\hline 22. & S. reticulate & - & - & - & 1.63 & Similar \\
\hline
\end{tabular}

Table 3 showed that presence frequency and distribution of teripang exhibited a difference in each location depending on suitable habitat. The highest presence frequency of teripang ranged from 0.92 to $30.79 \%$ (Table 3). The highest presence frequency of teripang was B. similis (30.79\%) followed by $\mathrm{H}$. leucospilota $(28.87 \%)$, Opheodosoma grisea $(25.80 \%)$ and $\mathrm{H}$. atra $(25.20 \%)$. The other teripang species had presence frequency less than $25.20 \%$. B. similis was found on pasir substrate and had an associate with overgrown Sea grass in Suli State Waters. As reported by Purwati (2005) that $B$. similis was found on sandy substrate which was grown by Sea grass. On the died reef substrate in Suli, it was obtained only one species of teripang namely A. mauritiana and the only one teripang species namely $H$. rigida was found on sandy substrate which was grown by Sea grass in the same State. The similar study was also reported by Aziz (1996) who investigated that A. mauritiana more grew on caloran of coral reef whilst, $H$. rigida dipped itself in Sea grass area [3],[26]

Distribution pattern of organisms in nature is divided by three main categories namely; similar, group and random [15]. Table 3 displayed that species of teripang found indicated these three distribution patterns. Each teripang species showed the different distribution pattern except Bohadschia marmorata (random \& group) and B. similis (similar \& group).

According to Bakus (1973), distribution pattern of teripang was different depending on kind and habitual of teripang itself. Naturally, teripang group grows for example Holothuria scabra commonly grows along with 3-5 individues. [27],[28]. The similar distribution pattern of teripang only occurs if there is the presence of competition among individues in the very hard community or the existence of positive difference causing the increasing of division of spaces in the community. In turn, group distribution pattern is the most common pattern and regulation on each individue. [6], [29] . 


\subsection{Diversity}

Species diversity of teripang was determined by the number spesies and individue abundance of each species. The analysis of species diversity in Central Moluccas Waters by Shannon index $\left(\mathrm{H}^{\prime}\right)$ ranged from 1.63 - 1.96 (Table 12). This value indicated the existence of low diversity. As reported by Odum (1975), criteria of Shannon index $\left(\mathrm{H}^{\prime}\right)$ are $0-4$. If Shannon index is less than 2 it shows the low species diversity in turn, if that reaches 4 it exhibits the high species diversity. In North Minahasa, teripang diversity value obtained was higher ranging from 2.31 to 2.49 [16], [25].

The highest species diversity value was found in Pelauw State Waters and the lowest species diversity was obtained in Ihamahu State Waters. It was proved by the higher number species and species abundance obtained in Pelauw State Waters than in other States.

Indeks keserasian (e) spesies in each location was found to be in stable condition. It showed there was no competition among species. According to Magurran (1991), index criteria of concurence showing the stabil condition was if concurence index ranges from 0 to 1 . It indicates that the individue abundance among species is almost similar [30].

Species dominance index (D) in each location showed that there has not been the occurence of species dominance eventhough, there have been several species showing the high individue number. It was supported by Odum (1971) who reported that domonance index criteria (D) ranges from yang 0 to 1 . If dominance index similar to 0 there has been no the presence of species dominance and if dominance index almost 1 it can be said that it occured species dominance in the community. Species number having the highest individue number in each location can be seen of the N1 value [13].

The occurence of environment pressure level increasing in the community has commonly the effect in the decreasing existence of species variety ( $\left.\mathrm{H}^{\prime}\right)$ and concurence (e) and the increasing presence of species dominance. If there is the change of species variety and concurence it will affect on species dominance.[31]

Table 4. Ecological parameter value based on species abundance in Weda Island Waters

\begin{tabular}{|c|c|c|c|c|}
\hline Parameter & Suli & Morela & Pelauw & Ihamahu \\
\hline S & 8 & 8 & 11 & 10 \\
\hline $\mathrm{N}$ & 74 & 88 & 390 & 404 \\
\hline $\mathrm{H}^{\prime}$ & 1.63 & 1.69 & 1.96 & 1.85 \\
\hline $\mathrm{D}$ & 0.23 & 0.21 & 0.17 & 0.19 \\
\hline 1-D & 0.77 & 0.79 & 0.83 & 0.80 \\
\hline $\mathrm{e}^{\prime}$ & 0.78 & 0.81 & 0.82 & 0.80 \\
\hline $\mathrm{N} 1$ & 5.07 & 5.41 & 7.07 & 6.34 \\
\hline
\end{tabular}

Note: $\mathrm{S}$ - Spesies number, $\mathrm{N}$ - individue number, $\mathrm{H}^{\prime}-$ Shannon index, $\mathrm{D}-$ Dominance index, Simpson - 1-D diversity index, e' - Evenness index, N1 - Hill dominance index

\section{Species Similarity}

The presence of teripang species in each location depended on the condition of location phisical with species similarity among locations reach $16.40 \%$ and range from $17.07 \%-35.80 \%$. It showed the existence of the high species difference level namely $83.60 \%$ (Figure 2 ).

Figure 2 showed the existence of two groups of teripang based on the location namely; group 1 SuliMorela and group 2 Pelauw-Ihamahu. Suli \& Morela State Waters had the similar species number of 8 species in which three of them could be found in two lacations namely; Bohadschia marmorata, Holothuria. atra and H. leucospilota. Although Pelauw State Waters had the less higher species number (11 species) than Ihamahu state Waters (10 spesies) There were found six teripang species in the two locations namely; Bohadschia marmorata, B. similis, H. atra, H. scabra, Actinopyga echinites, and Opheodosoma grisea. 


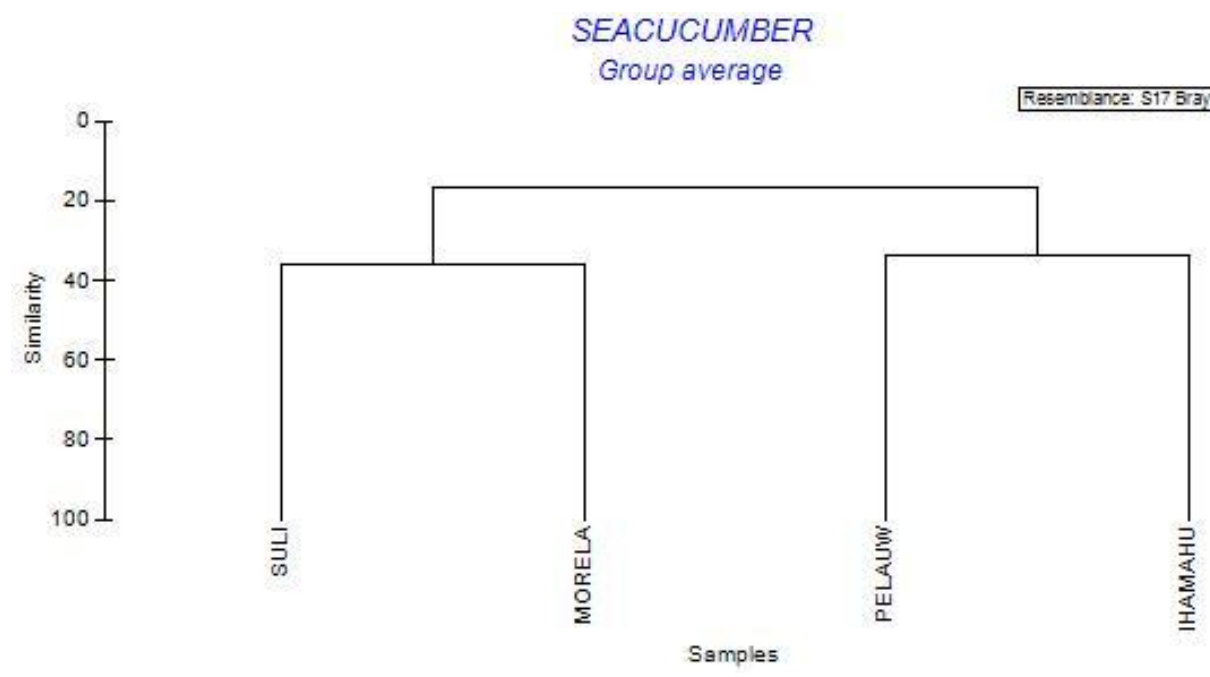

Figure 2. Species similarity of teripang among four locations in Central Moluccas

The highest species similarity was found to be occurred in Suli-Morela State Waters $(35.80 \%)$, followed by Pelauw-Ihamahu, Pelauw-Morela, Ihamahu-Morela, Suli-Ihamahu, and the lowest was obtained in Pelauw-Suli State Waters (Table 5). It indicated the presence of high teripang species difference among locations in which only special species could be found in the four locations.

Table 5. Similarity value (\%) of teripang species in the four locations in central Moluccas

\begin{tabular}{|l|r|l|l|l|}
\hline & \multicolumn{1}{|l|}{ SULI } & MORELA & PELAUW & IHAMAHU \\
\hline SULI & & & & \\
\hline MORELA & 35.80247 & & & \\
\hline PELAUW & 14.22414 & 17.57322 & & \\
\hline IHAMAHU & 16.7364 & 17.07317 & 33.50126 & \\
\hline
\end{tabular}

\section{Conclusion And Suggestion}

This study showed that the relative chemical physical parameters were suitable for the growth of teripang species. There were 22 species of teripang which were found in Central Moluccas. Three species of them have the high economical value and two species have the moderate economical value. Species density and presence frequence of teripang species in each location were different depended on local ecological condition. In general, species density of teripang was obtained to be in low category. Distribution pattern of teripang species found was group, similar and random. Diversity of teripang species in Central Moluccas was in low category. The low category was also shown by species similarity among locations.

Therefore, it is suggested to study about ecological (waters quality, habitat and resource condition), economical social (local wisdom) and institutional aspects.

\section{Acknowledgement}

The authors thanked DP2M DIKTI, Indonesia for funding research through SKIM MP3EI (PENPRINAS MP3EI 2011-2025) in 2013 and students joining in this research.

\section{References}

[1] Yusron, E., Sumberdaya teripang di perairan Tanjung Pai Padaido Biak Numfor - Papua. Makara Sains 8 (3). 2004, 123-127

[2] Wiadnyana, N.N., R. Puspasari, and R.T., Mahulette, Status sumber daya dan perikanan teripang di Indonesia: Pemanfaatan dan Perdagangan. J. Kebijak. Perikan. Ind. 1(1). 2009, 45-60

[3] Purwati, P., Teripang Indonesia: Komposisi jenis dan sejarah perikanan. In. Oseania. XXX. 2. 2005, 11-18.

[4] Preston, G.L, Beche-de-mer. In: Nearshore Marine Resources of the South Pacific: Information for Fisheries Development and Management A. Wright \& L. Hill, eds., Forum Fishe-ies Agency, Honiara, Solomon Islands. 1993, 371-407.

[5] Akamine, J, Sea cucumbers from the coral reef to the world market. In Bisayan knowledge, movement and identity. VMAS III 1996-1999 (I. Ushijima \& C. N. Zayas eds.). Quezon city, University of the Philippines. 2000, 223-244.

[6] Yusron, E, Struktur komunitas teripang (Holothuroidea) di Rataan Terumbu Karang Perairan Pantai Morela, Ambon. Dalam Pesisir dan Pantai Indonesia VI. Pusat Penelitian dan Pengembangan Oseanologi - LIPI. Jakarta : Seri II. 2001,8 hal.

[7] Solihin, A, Sasi Teripang: Upaya konservasi dalam membangun desa. Prosiding Seminar Nasional Pengembangan Pulau-Pulau Kecil. 2001.

[8] Dinas Perikanan Kabupaten Maluku Tenggara, Data produksi perikanan Kabupaten Maluku Tenggara. Maluku Tengara In Angka. BPS Kabupaten Maluku Tenggara 2012. 
[9] Malik, S.A., Kajian struktur komunitas; Pola penyebaran dan pemanfaatan teripang (Holothuridae) dalam Upaya Pengelolaan di Pesisir Pantai Desa Morela, Pulau Ambon. Skripsi, 2013. Unpublished.Fakultas Perikanan dan Ilmu Kelautan Unpatti.

[10] Clark, A. M. and F. E. W. Rowe. Monograph of the Shallow waters Indo-West Pacific, Echinoderms. Trust. Brit. Mus. Nat. Hist. . $1971,228$.

[11] Susetiono, Fauna padang lamun Tanjung Merah, Selat Lembeh. Pusat Penelitian Oseanografi - LIPI, 2004, Jakarta.

[12] Susetiono, Lamun dan fauna Teluk Kuita, Pulau Lombok. Pusat Penelitian Oseanografi - LIPI. 2007, Jakarta.

[13] Odum, E. P., Fundamental of Ecology. W.B. Sanders Company. 1971. USA.

[14] Khouw, A. S. K., Metode dan analisa kuantitatif dalam bioekologi laut. pusat pembelajaran \& pengembangan pesisir dan laut (P \& L) Dirjen Kelautan Pesisir \& Pulau-Pulau Kecil (KP3K). 2009, DKP.RI.

[15] Bakus, G.J., Quantitative analysis of marine biological communities: Field Biology and Environment.. Wiley Interscience. Los Agels. US. 2007, 435 pages

[16] Odum, E. P, Ecology. The Link Between The Natural And The Social Science. Second Edition, Rienhart And Winston. 1975, 5356.

[17] Darsono, P, Sumber Daya Teripang dan Pengelolaannya. In. Oseania XXVII:2 2003. 1-9

[18] Gultom, C. P., Laju pertumbuhan dan beberapa aspek bio-ekologi teripang pasir (Holotothuria scabra) dalam kolam pembesaran di laut Pulau Kongsi, Kepulauan Seribu, Jakarta Utara. Skripsi. Departemen Ilmu dan Kelautan, Fakultas Perikanan dan Ilmu Kelautan. Institut Pertanian Bogor. Bogor. 2004, 67 hlm.

[19] Martoyo, J., N. Aji and T. Winanto. 1994. Budidaya teripang. Penebar Swadaya.1994, Jakarta.

[20] Yusron, E. and P. Widianwari, Struktur komunitas teripang (Holothuroidea) di beberapa perairan pantai Kai Besar, Maluku Tenggara. Makara Sains 8 (1). 2004, 15 - 20.

[21] Sukmiwati, M. S. Salmah. S. Ibrahim. D. Handayani and P. Purwati, Keanekaragaman teripang (Holothuroidea) di Perairan Bagian Timur Pantai Natuna Kepulauan Riau. Jurnal Natur Indonesia. 14 (2). 2012, 131 - 137.

[22] Direktorat Konservasi and Tanaman Nasional Laut (2004)

[23] Keputusan Menteri Lingkungan Hidup No 51/2004

[24] Agusta, O. R. B. Sulardiono. and S. Rudiyanti, Kebiasaan makan teripang (Echinodermata: Holothuriidae) di Perairan pantai Pulau Pramuka, Kepulauan Seribu. Journal Of Management Of Aquatic Resources. 1 (1).2012, 1-8.

[25] Yusron, E. Keanekaragaman jenis teripang (Holothuroidea) di perairan Minahasa Utara Sulawesi Utara. Oseanologi dan Limnologi di Indonesia 35(1). 2009, 19-28

[26] Aziz A, Status penelitian teripang komersial di Indonesia. Oseana. 22 (1).1996, 9 - 19.

[27] Bakus, G.J, The Biology and ecology of holothurians. Academi Press. 1973, New York.

[28] Sutaman, Petunjuk praktis budidaya teripang. Kanisius. Yogyakarta. 1993, 13-25.

[29] Hetty and Kurniaty., 1994. Prinsip dasar ekologi, Suatu bahasan tentang kaidah ekologi dan penerapannya. Raya Grafindo Persada, Jakarta.1994. Hal 272.

[30] Magurran, A.E., 1991. Ecological diversity and its measurement. Chapman and Hall. London

[31] Clarke, K. R. and R. M. Warwick. 1994. Change in marine communities: an approach to statistical analysis and interpretation. Plymouth Marine laboratory. 